\title{
Kajian Pemanfaatan Limbah Jerami Sebagai Pakan Ternak Sapi di Provinsi Aceh
}

\section{The Study of Rice Straw Utilization for Cattle Feed Supplement in Aceh Province}

\author{
Y. Yusriani ${ }^{1}$, Elviwirda ${ }^{1}$ dan M. Sabri ${ }^{2}$ \\ ${ }^{1}$ Balai Pengkajian Teknologi Pertanian Aceh \\ ${ }^{2}$ Fakultas Kedokteran Hewan Unsyiah, Banda Aceh \\ email: yenniyusriani@ymail.com \\ (Diterima: 20 Januari 2015; Disetujui: 2 April 2015)
}

\begin{abstract}
ABSTRAK
Kajian Pemanfaatan Limbah Jerami sebagai Pakan Ternak Sapi di Kabupaten Aceh Timur Provinsi Aceh bertujuan untuk mengintroduksikan teknologi pakan sapi berbasis jerami padi. Prosedur penelitian yang dilakukan meliputi koordinasi dengan Dinas Pertanian dan Peternakan, Kabupaten Aceh Timur dimaksudkan untuk mengetahui permasalahan dan kebutuhan teknologi, pembuatan fermentasi jerami padi dengan menggunakan probiotik, pembuatan urea molases blok, pelaksanaan introduksi dan manajemen teknologi pakan. Ternak yang digunakan sebanyak 9 ekor berdasarkan berat badan berkisar antara $100-300 \mathrm{~kg}$. Ada tiga perlakuan ransum yang digunakan terdiri dari : R0 : Perlakuan petani (jerami + konsentrat) ; R1 : Hijauan 30\% (15\% rumput gajah + $15 \%$ rumpul gamal) + Jerami Fermentasi 70\% + Mineral blok + Konsentrat (jagung+ dedak), ; R2 : Hijauan 70\% (35\% rumput gajah $+35 \%$ rumpul gamal) + Jerami Fermentasi 30\% + Mineral blok + Konsentrat (jagung+ dedak). Pengamatan yang dilakukan meliputi pertambahan berat badan, konsumsi ransum, konversi. Hasil penelitian menunjukkan bahwa pertambahan bobot hidup harian (PBHH) tertinggi dijumpai pada perlakuan R2 sebesar 0,82 kg/ekor/hari dan terendah pada perlakuan R0 sebesar 0,60 kg/ekor/hari. Pola pemberian ransum Hijauan 70\% (35\% rumput gajah + 35\% rumpul gamal) + Jerami Fermentasi 30\% + Mineral blok + Konsentrat (jagung+ dedak) yaitu (R2) memberikan pertambahan bobot hidup harian (PBHH) yang optimal. Hasil pengkajian ini menunjukkan bahwa formula pakan pada perlakuan R2 lebih efisien dengan formula pakan pada perlakuan lainnya.
\end{abstract}

Kata kunci: jerami padi fermentasi, limbah, sapi potong

\section{ABSTRACT}

The study of rice straw utilization as cattle feed supplement in East Aceh district of Aceh province was aimed at introducing the rice straw technology to beef cattle feed. A number of steps had been taken into account; (1) the coordination with East Aceh Department of Agriculture and Livestock to identify the problem of fermented rice straw technology using probiotics, (2) the manufacture of urea molasses block, and (3) managing the introduction and application of cattle feed technology. Nine heads of cattle with 100-300 kg weight were treated with three types of rations; $R 0$ was farmers' treatment (hay + concentrate); R1: Forage 30\% $(15 \%+15 \%$ elephant grass + gliricidia sepium $)+$ fermented straw $70 \%+$ block + mineral concentrate $(+$ corn bran $) ;$ R2: Forage $70 \%(35 \%+35 \%$ elephant grass + gliricidia sepium $)+$ fermented straw $30 \%+$ block + mineral concentrate $(+$ corn bran). Observed indicators were daily weight gain, feed consumption, and feed conversion. The results showed that the highest daily weight gain was in $R 2$ with $0.82 \mathrm{~kg} /$ day and the lowest was in R0 with $0.60 \mathrm{~kg} /$ day. Ration composition (R2) with forage $70 \%(35 \%$ elephant grass $+35 \%$ gliciridia sepium $)+$ fermented straw $30 \%+$ block + mineral concentrate (+ corn bran)) provided an optimal daily weight gain. Therefore the $R 2$ is the most efficient treatment for cattle feed formula in East Aceh.

Keywords: agricultural by-products, beef cattle, fermented rice straw 


\section{PENDAHULUAN}

\begin{abstract}
Meningkatnya produksi daging merupakan salah satu upaya untuk mewujudkan ketahanan pangan sekaligus memajukan tingkat kecerdasan sumberdaya manusia. Daging sapi adalah sumber protein hewani yang kontribusinya dalam memenuhi kebutuhan konsumen nasional sekitar 23\% (Marsetyo, 2009). Menurut Haryanto (2003), produksi jerami padi dapat mencapai 12 - 15 ton/ha/panen, bervariasi tergantung pada lokasi dan jenis varietas tanaman padi yang digunakan. Jerami padi yang dihasilkan dapat digunakan sebagai pakan sapi dewasa sebanyak 2-3 ekor pertahun dan pada lokasi yang mampu panen 2 - 4 kali setahun akan dapat menunjang kebutuhan pakan berserat untuk 4 - 6 ekor. Di samping itu, dedak padi yang dihasilkan dapat digunakan sebagai salah satu komponen bahan pakan untuk menyusun ransum ternak.
\end{abstract}

Sebagai bahan pakan, jerami padi memiliki kandungan gizi yang rendah sehingga perlu adanya teknologi fermentasi yang sederhana, maka untuk mengatasi kekurangan rumput ataupun hijauan pakan lainnya salah satunya adalah pemanfaatan limbah pertanian sebagai pakan (Kasryno dan Syafa'at, 2000). Menurut Shanahan et al. (2004), bahwa kendala pemanfaatan limbah pertanian sebagai pakan ternak adalah pada umumnya memiliki kualitas rendah dengan kandungan serat yang tinggi, akibatnya apabila digunakan sebagai pakan basal dibutuhkan penambahan bahan pakan yang memiliki kualitas yang baik antara lain konsentrat untuk memenuhi dan meningkatkan produktivitas ternak.

Sugeng (2006), menyatakan bahwa sistem penggemukan sapi secara intensif merupakan pemeliharaan sapi di dalam kandang terus-menerus pada periode tertentu dengan pemberian pakan hijauan dan konsentrat. Kartono (2002), menyebutkan pada model integrasi tanaman ternak, petani mengatasi permasalahan ketersediaan pakan ternak dengan memanfaatkan limbah tanaman seperti jerami padi, jerami jagung dan limbah kacang-kacangan. Pada musim kemarau, limbah ini bisa menyediakan pakan berkisar 33,3 persen dari total rumput yang dibutuhkan (Kariyasa 2003). Lebih lanjut Chaniago (2009), tujuan integrasi tanaman dengan ternak adalah untuk mendapatkan produk tambahan yang bernilai ekonomis, peningkatan efisiensi usaha, peningkatan kualitas penggunaan lahan, peningkatan kelenturan usaha menghadapi persaingan global, dan menghasilkan lingkungan yang bersih dan nyaman.

Permasalahan yang dihadapi petani dalam usahatani padi saat ini adalah menurunnya produktivitas lahan sawah, keterbatasan penyediaan pupuk kandang dan pakan ternak, serta aspek lingkungan. Permasalahan tersebut diharapkan dapat diatasi secara simultan dengan menerapkan sistem integrasi padi-sapi. Untuk mendapatkan manfaat yang optimal dari sistem integrasi padi-sapi di lahan sawah perlu dipadukan antara kepentingan ekonomi, sosial-budaya, dan kelestarian lingkungan.

Kabupaten Aceh Timur Provinsi Aceh merupakan suatu kawasan pengembangan pertanian dan peternakan. Ternak sapi dan tanaman padi adalah dua komoditi andalan di kabupaten ini, yang dapat bersinergi. Oleh sebab itu potensi yang ada di provinsi Aceh, dapat dioptimalkan dalam satu sistem usaha tani yang terintegrasi maupun efisiensi usahatani, akibat melimpahnya limbah pertanian saat musim panen perlu penanganan pengawetan dengan jalan fermentasi, di samping salah satu upaya untuk meningkatnya kandungan protein kasar sekitar 8\% (Djajanegara, et al., 2001). Semua itu dapat dicapai dengan pendekatan berkelanjutan yang memanfaatkan sumber pakan lokal, melalui inovasi teknologi limbah pertanian sebagai sumber pakan sapi yang berpotensial untuk penggemukan dan pembibitan serta bebas dari polusi udara akibat pembakaran limbah.

Pengkajian ini bertujuan untuk: Mengintroduksikan teknologi pakan sapi berbasis jerami padi dan teknologi pengolahan pupuk organik padat yang berasal dari kotoran sapi untuk tanaman padi. 


\section{METODE}

Pengkajian ini dilakukan di lahan milik petani yang dilaksanakan oleh petani. Lokasi pengkajian dilaksanakan di Kabupaten Aceh Timur, Provinsi Aceh pada bulan Maret Desember 2014.

Pengkajian ini menggunakan sapi yang dipelihara di areal petani kooperator. Ternak yang digunakan sebanyak 9 ekor sapi dengan bobot badan rata-rata berkisar $150-300 \mathrm{~kg}$ yang dikelompokkan berdasarkan rataan bobot badan. Sapi dipelihara menggunakan kandang individu bersekat sebanyak 9 buah yang dilengkapi dengan tempat makan dan air minum. Kandang ditempatkan dalam bangunan kandang utama yang permanen dan beratap sehingga sirkulasi udara baik dan peningkatan suhu kandang yang berlebihan tidak terjadi. Pakan berupa jerami padi fermentasi, hijauan dan konsentrat diberikan $1 \%$ dari bobot badan. Ternak diberi pakan dua kali sehari, pagi hari dan siang hari dan air minum diberikan secara ad libitum. Komposisi ransum selama penelitian dapat dilihat pada Tabel 1.

Sapi yang digunakan dalam pengkajian sebelumnya mendapat perlakuan obat cacing (ivomex) dan vitamin Hematofan, untuk komposisi vitamin dapat dilihat pada Tabel 2.

Pengkajian menggunakan Rancangan Acak Kelompok (RAK) dengan 3 perlakuan dan 3 ulangan. Ternak yang digunakan sebanyak 9 ekor sapi yang berasal dari peternak kooperator. Sebelum diberikan untuk ternak, jerami padi difermentasikan terlebih dahulu.

Pertambahan bobot badan dilakukan dengan menimbang ternak sebulan sekali. Pertambahan bobot badan harian dihitung dengan cara mengurangi bobot badan akhir dengan bobot badan awal dibagi dengan jumlah hari selama penelitian. Jumlah konsumsi ransum dihitung dari jumlah

Tabel 1. Komposisi ransum selama penelitian (\%).

\begin{tabular}{lccc}
\hline \multicolumn{1}{c}{ Komposisi Bahan } & \multicolumn{2}{c}{ Perlakuan } \\
\cline { 2 - 4 } & R0 & R1 & R2 \\
\hline A. Hijauan & 0 & 15 & 35 \\
$\quad$ Rumput gajah & 0 & 15 & 35 \\
$\quad$ Rumput gamal & 100 & 0 & 0 \\
B. Jerami tanpa fermentasi & 0 & 70 & 30 \\
C. Jerami fermentasi & & & \\
D. Konsentrat & 0,3 & 0,3 & 0,3 \\
$\quad$ Jagung & 0,7 & 0,7 & 0,7 \\
$\quad$ Dedak & & & \\
\hline
\end{tabular}

Ket : R0 : Perlakuan petani (jerami + konsentrat); R1 : Pemberian hijauan 30\% (15\% rumput gajah $+15 \%$ rumpul gamal) + Jerami Fermentasi 70\% + Mineral blok + Konsentrat (jagung+ dedak); R2 : Pemberian hijauan 70\% (35\% rumput gajah $+35 \%$ rumpul gamal) + Jerami Fermentasi 30\% + Mineral blok + Konsentrat (jagung+ dedak)

Tabel 2. Kandungan komposisi vitamin hematopan setiap ml.

\begin{tabular}{lc}
\hline Komponen & Jumlah \\
\hline Natrium kakodilat & $30 \mathrm{mg}$ \\
Amonium sitrat & 20 \\
Metionin & 10 \\
Histidin & 5 \\
Triptopan & 2,5 \\
Vitamin -B12 & 10 \\
\hline
\end{tabular}


pemberian dikurangi dengan ransum yang tersisa. Konversi ransum dhitung dengan membagi konsumsi dan pertambahan berat badan.

Peubah yang diamati adalah : (1) pertambahan bobot badan, (2) konsumsi ransum, (3) konversi. Data hasil pengamatan diolah secara statistik diuji dengan menggunakan sidik ragam (Program SPSS 16). Apabila hasil sidik ragam berbeda nyata maka dilanjutkan dengan uji DMRT pada taraf 0,05 dan jika terdapat perbedaan dilakukan dengan uji lanjut (Steel \& Torrie 1991).

\section{HASIL DAN PEMBAHASAN}

\section{Koordinasi dan Penentuan Lokasi}

Hasil koordinasi dengan Dinas Peternakan Kabupaten Aceh Timur untuk penentuan lokasi menetapkan bahwa Kelompok Jasa Usaha yang terletak di daerah Gampong Seuneubok Jalan. Daerah ini merupakan salah satu gampong yang diapit oleh beberapa gampong lainnya yaitu Gampong Blang Siguci, Desa Seuneubok Dalam, Buket Teukuh, Blang Menjei. Desa Seuneubok Jalan berada dalam kemukiman Desa Blang Siguci, Kecamatan Idi Tunong Kabupaten Aceh Timur.

Abdullah (2008), menyatakan bahwa dalam pemanfaatan jerami padi dibutuhkan suplementasi bahan yang berkualitas kemudian diolah agar nilai gizinya dapat ditingkatkan serta dapat meningkatkan bobot badan hewan ternak. Manajemen pemeliharaan usahatani ternak umumnya masih dilakukan secara konvensional dan tradisional. Kendala utama yang dihadapi petani yang belum memadukan usaha ini dengan tanaman pertanian adalah tidak tersedianya pakan secara memadai terutama pada musim kemarau. Terlebih untuk daerah dengan kondisi iklim yang cenderung kering, dimana musim kemarau juga berlangsung lebih panjang. Kesulitan pakan terutama pada musim kemarau dapat diatasi dengan memanfaatkan limbah atau hasil samping tanaman pertanian, seperti jerami padi yang jumlahnya cukup melimpah pada saat panen.

\section{Pembuatan Jerami Padi Fermentasi untuk Pakan Ternak}

Pengembangan sapi potong perlu dilakukan melalui pendekatan usaha yang berkelanjutan, modern, dan profesional dengan memanfaatkan inovasi teknologi untuk meningkatkan efisiensi usaha. Sistem integrasi tanaman ternak mengemban tiga fungsi pokok yaitu memperbaiki kesejahteraan dan mendorong pertumbuhan ekonomi, memperkuat ketahanan pangan dan memelihara keberlanjutan lingkungan. Kandungan nutrisi jerami padi dan jerami padi fermentasi disajikan di Tabel 3.

\section{Pembuatan Urea Molases Blok (UMB)}

Devendra (1988), menyatakan bahwa Urea Molasses Block (UMB) merupakan suplementasi mineral dalam bentuk blok dengan bahan baku lokal sebagai bahan baku utama terutama dari limbah industri pertanian dan pakan non konvensional yang ketersediaannya murah dan mudah diperoleh. Urea Molases Block adalah pakan suplemen untuk ternak ruminansia, berbentuk padat yang kaya dengan zat-zat makanan. Thu dan Uden (2000) menambahkan bahwa UMB merupakan suplemen mineral dalam bentuk blok yang terdiri dari bahan-bahan berupa

Tabel 3. Kandungan Nutrisi Jerami Padi dan Jerami Padi Fermentasi (\%)

\begin{tabular}{llllllll}
\hline \multirow{2}{*}{ Bahan baku } & \multicolumn{7}{c}{ Hasil Analisi Proksimat } \\
\cline { 2 - 8 } & BK & PK & LK & SK & Abu & BETN & TDN \\
\hline Jerami padi & 87,58 & 4,21 & 10,60 & 24,76 & 19,05 & 40,78 & 41,68 \\
Jerami padi fermentasi & 89,18 & 7,09 & 15,0 & 18,44 & 20,30 & 35,69 & 48,63 \\
\hline
\end{tabular}

Sumber : Basuni et al. (2010)

Ket $:$ BK = Bahan kering ; PK = Protein Kasar ; LK = Lemak Kasar ; SK = Serat Kasar; BETN = Bahan ekstrak tanpa nitrogen $;$ TDN = Total digestible nutrien. $(\mathrm{TDN}$ adalah total energi zat makanan pada ternak yang disetarakan dengan energi dari karbohidrat, digunakan untuk mengukur kandungan energi dari bahan-bahan makanan) 
Proses Pengolahan fermentasi sebagai berikut

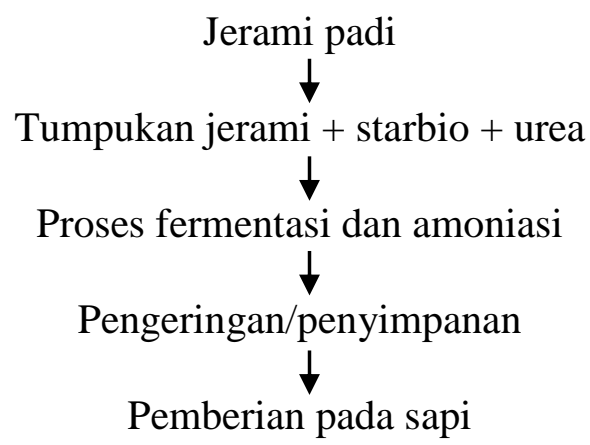

Gambar 1. Proses Jerami Padi Fermentasi (Haryanto et al. 2003).

molases, urea, singkong, minyak biji-bijian dan mineral. Bahan-bahan tersebut berfungsi sebagai sumber energi mudah tercerna, sumber $\mathrm{N}$ dan sumber mineral yang dapat meningkatkan pertumbuhan mikroba rumen untuk memperbaiki nutrisi ternak sebagai induk semang. Pakan suplemen ini dapat juga disebut sebagai "permen jilat" untuk ternak, yang dapat digunakan untuk ternak-ternak yang dikandangkan ataupun yang digembalakan.

Hatmono dan Indriyadi (1997), menyatakan bahwa manfaat UMB antara lain untuk meningkatkan produktifitas ternak melalui peningkatan sintesa protein oleh mikroba di dalam rumen, peningkatan kecernaan pakan dan peningkatan konsumsi pakan yang semuanya itu akan memberikan keseimbangan yang lebih baik antara suplai asam amino dan energi dan kebutuhan ternak untuk tumbuh, berproduksi, hal ini meningkatkan populasi mikroorganisme rumen sehingga kebutuhan serat kasar sebagai media hidupnya akan meningkat pula, sehingga akan merangsang ternak untuk mengkonsumsi bahan pakan lebih banyak dari keadaan normalnya, dengan meningkatnya konsumsi pakan maka produksi ternak (daging) akan meningkat pula.

\section{Performa Sapi Selama Penelitian}

Jerami padi merupakan limbah pertanian yang memiliki kualitas rendah, namun dapat dimanfaatkan sebagai pakan ternak dengan diolah terlebih dahulu untuk pengayaan nutrisi pakan. Teknologi fermentasi cukup tepat untuk dilakukan, karena mampu meningkatkan kandungan protein kasar dan energinya, serta produk ini dapat disimpan dalam waktu yang cukup lama sehingga mampu mengatasi kesulitan pakan di musimmusim tertentu. Penambahan jerami padi fermentasi dan hijauan dalam ransum perlakuan untuk sapi potong memberikan performans yang berbeda dibandingkan tanpa penambahan jerami padi fermentasi dan hijauan.

Rataan pengaruh perlakuan terhadap bobot badan, pertambahan bobot badan, konsumsi ransum dan konversi ransum sapi yang diberi jerami padi fermentasi selama 5 bulan penelitian disajikan pada Tabel 4 .

Pemberian pakan jerami padi fermentasi berpengaruh nyata $(\mathrm{P}<0,05) \quad$ terhadap pertambahan bobot badan harian sapi. Rataan pertambahan bobot badan harian sapi berkisar antara $0,60-0,82 \mathrm{~kg} / \mathrm{ekor} / \mathrm{hari}$ yang tertinggi terdapat pada perlakuan R2 ( Pemberian hijauan $70 \%$ (35\% rumput gajah $+35 \%$ rumpul gamal) + Jerami Fermentasi 30\% + Mineral blok + Konsentrat (jagung+ dedak) sebesar 9,83 kg/ekor/hari. Hal ini berarti bahwa respon pertumbuhan ternak dapat ditingkatkan dalam penelitian ini oleh penambahan probiotik di dalam pakan jerami padi fermentasi. Usaha penggemukan sapi ini bukan untuk meningkatkan nilai PBBH saja, tetapi juga memanfaatkan jerami padi untuk ternak. Pemanfaatan jerami secara optimal akan menekan biaya produksi dan ramah lingkungan.

Pemberian pakan jerami padi fermentasi berpengaruh nyata $(\mathrm{P}<0,05) \quad$ terhadap konsumsi pakan sapi. Pakan jerami padi fermentasi mengandung energi yang dapat dimanfaatkan lebih tinggi dibanding dengan jerami padi tanpa fermentasi. Suharto dan Rosanto (1993) menyatakan bahwa pada sapi, salah satu kegunaan dari probiotik dalam pakan adalah sebagai zat pengurai selulosa, lemak, lignin, dan protein sehingga dapat meningkatkan daya cerna nutrisi ternak. Hal ini dimungkinkan pada kandungan serat yang lebih rendah peranan bakteri pemecah serat 
lebih optimal sehingga daya cerna ternak terhadap pakan menjadi lebih baik.

Menurut Siregar (2008), bahwa konversi pakan yang baik pada hewan ternak sapi adalah 8,56-13,29. Nilai konversi pakan juga menggambarkan nilai efisiensi penggunaan pakan. Purbowati et al. (2005), menyatakan bahwa efisiensi pakan pada penggemukan sapi muda jauh lebih tinggi dibandingkan dengan penggemukan sapi dewasa. Hal ini menyebabkan pertambahan bobot badan dan efisiensi pakan pada sapi muda sangat tinggi dibanding dengan sapi dewasa. Meningkatnya pakan penguat atau semakin baiknya kualitas pakan akan menyebabkan semakin baik pula efisiensi penggunaannya oleh ternak. Konversi pakan yang bagus pada pengkajian ini terdapat pada penambahan pemberian hijauan $70 \%$ $(35 \%$ rumput gajah $+35 \%$ rumpul gamal $)+$ Jerami Fermentasi 30\% + Mineral blok + Konsentrat (jagung+ dedak) yaitu R2 sebesar 12,1 dilanjutkan dengan pemberian hijauan $30 \%$ (15\% rumput gajah $+15 \%$ rumpul gamal) + Jerami Fermentasi $70 \%$ + Mineral blok + Konsentrat (jagung+ dedak) yaitu R1 sebesar 12,7 dan yang terakhir R0 = Perlakuan petani ( jerami + konsentrat) sebesar 15,4.

\section{KESIMPULAN}

Pertambahan bobot hidup harian (PBHH) tertinggi dijumpai pada perlakuan R2 sebesar $0,82 \mathrm{~kg} / \mathrm{ekor} / \mathrm{hari}$ dan terendah pada perlakuan R0 sebesar 0,60 kg/ekor/hari. Pola pemberian ransum Hijauan 70\% (35\% rumput gajah $+35 \%$ rumpul gamal) + Jerami Fermentasi 30\% + Mineral blok + Konsentrat (jagung+ dedak) yaitu (R2) memberikan pertambahan bobot hidup harian $(\mathrm{PBHH})$ yang optimal. Hasil pengkajian ini menunjukkan bahwa formula pakan pada perlakuan R2 lebih efisien dengan formula pakan pada perlakuan lainnya.

\section{SARAN}

Perlu ada kajian atau penelitian lanjutan untuk pengaplikasian pupuk organik berupa kompos pada tanaman padi serta mengetahui produktivitas dari tanaman padi sebelum dan setelah pemberian pupuk organik.

\section{DAFTAR PUSTAKA}

Abdullah, 2008. Pembuatan jerami padi amoniasi sebagai sumber pakan ternak potensial di Kecamatan Ujung Loe Kabupaten Bulukumba, Program Penerapan IPTEKS.

Basuni et al. 2010. Sistem integrasi padisapi potong di lahan sawah. Jurnal IPTEK Tanaman Pangan. Vol 5 No 1,2010 .

Chaniago, T. 2009. Perspektif pengembangan ternak sapi di kawasan perkebunan. Prosiding Workshop Nasional Dinamika dan Keragaan Sistem Integrasi Ternak - Tanaman: Padi, Sawit, Kakao. (In Press). Pusat Penelitian dan Pengembangan Peternakan. Bogor.

Devendra, C. 1988. Non-Conventional Feed Resources in Asia and Pacific. Advenches in Avaibility and Utilization. 3th Edition. FAO. Rome.

Djajanegara, A., B. Risdiono, A. Priyanti, D. Lubis dan K. Diwiyanto. 2001. CropAnimal Systems Research Network (CASREN) Indonesia. Laporan Pengkajian. Pusat Pengkajian dan Pengembangan Peternakan. Bogor.

Haryanto, B., I. Inounu, I.G.M. Budiarsana, dan K. Dwiyanto. 2003. Panduan teknis integrasi padi-ternak (SIPT). Departemen Pertanian.

Hatmono, H. dan H. Indriyadi. 1997. Urea Molase Blok Pakan Suplemen untuk Ternak Ruminansia. PT. Trubus Agriwidya. Ungaran.

Kasryno, F., N. Syafa'at, 2000. Strategi pembangunan pertanian yang berorientasi pemerataan di tingkat petani, sektoral dan wilayah. prosiding perspektif pembangunan pertanian dan pedesaan dalam era otonomi daerah. Pusat Penelitian Sosial Ekonomi 
Pertanian Badan Litbang Pertanian Departemen Pertanian, Jakarta.

Kariyasa K. dan E. Pasandaran. 2004. Dinamika struktur usaha dan pendapatan tanamanternak terpadu. Makalah disampaikan dalam Seminar Kelembagaan Usahatani Tanaman Ternak tanggal 30 Nopember - 2 Desember 2004 di Denpasar-Bali. Proyek PAATP. Jakarta.

Kartono. G.2002. Pengelolaan sumberdaya lahan dalam upaya peningkatan pendapatan petani dan keberlanjutan sistem usahatani. Prosiding. Seminar Nasional Inovasi Teknologi Tepat Guna Berorientasi Agribisnis untuk Pemberdayaan Pertanian Wilayah. Puslitbang Sosek Pertanian Bogor.

Marsetyo, 2009. Dinamika Penelitian Sawit terhadap Pengembangan Integrasi dengan Ternak Sapi.

Purbowati, W.S. Dilaga dan N.S.N Aliyah, 2005. Penampilan produksi Sapi Peranakan Ongole dan Peranakan Limousin Jantan dengan pakan konsentrat dan jerami padi fermentasi. Artikel_AINI_2005.
Shanahan, J.F., D.H. Smith., T.L. Stanton., B.E. Horn. 2004. Crop Residues For Livestock Feed. Colorado :CSU Cooperative Extention- Agriculture, Colorado State University. http://www.ext. colostate.edu/pubs/ crop/00551.html (15 september 2015).

Siregar, S.B. 2008. Penggemukan Sapi. Penerbit Swadaya. Jakarta Siregar,

Surya, dan Amri. 2009. Analisis pendapatan peternak sapi potong di Kecamatan Stabat, Kabupaten Langkat. Skripsi. Fakultas Pertanian, Universitas Sumatera Utara.

Sugeng, Y. B. 2006. Sapi Potong. Penebar Swadaya, Jakarta.

Suharto, W. dan Rosanto. 1993. Starbio untuk penggemukan ternak sapi. Fakultas Pertanian UNS, Surakarta.

Steel RGD, Torrie JH. 1991. Prinsip dan Prosedur Statistik Suatu Pendekatan Biometrik. Jakarta: Gramedia.

Thu, N. V \& P. Uden. 2000. Effect of work and urea-molasses cake supplementation on live weight and milk yield of Murrah Buffalo. AsianAustralia J. Anim. Sci.14 (9) : 13291336. 